\title{
Analisis Stres Kerja Di Masa Pandemi Covid-19 Pada Karyawan Mina Wisata Islami Tour and Travel Haji Umrah Surabaya
}

\author{
Aisyah Puteri Arini ${ }^{1}$, Airlangga Bramayudha ${ }^{2}$ \\ ${ }^{1,2}$ Universitas Islam Negeri Sunan Ampel Surabaya \\ 1.Arinnaisyah@gmail.com, ${ }^{2}$ bram@uinsby.ac.id
}

\begin{tabular}{l}
\hline Article Info \\
\hline Article history: \\
Received 7 Januari 2022 \\
Accepted 8 Januari 2022 \\
Published 8 Januari 2022 \\
Page : 25 - 46 \\
\hline
\end{tabular}

Keyword:

Stres Kerja, Work Stress, Stressors, Mina Wisata

Islami Tour and Travel Surabaya, Pandemi Covid19

\begin{abstract}
The purpose of this research is to describe the causal factors, countermeasures, and obstacles in overcoming work stress during the Covid-19 pandemic in Employees of Mina Wisata Islami Tour And Travel Haji Umrah Surabaya. This research uses qualitative research methods with case studies as a type of research. Case studies are used to observe, describe, and find a complete picture of the phenomenon related to work stress during the Covid-19 pandemic in employees of Mina Wisata Islami Tour and Travel Haji Umrah, Surabaya. The data collection technique used to dig up information from Mina Wisata Islami Tour and Travel Haji Umrah Surabaya is through interviews, observations and documentation.

As a result of research obtained by researchers in the field illustrates that the factors that cause work stress in Mina Wisata Islami employees are dominated by changes in conditions and unclear information simultaneously, so employees have no power over it. As for some other stressors that can trigger the onset of work stress for employees, namely work demands, time demands, dual roles, feedback that is felt less after when carrying out work, work environment conditions, and unhuffed authority to carry out responsibilities. Related to efforts to combat employee work stress using three methods, namely social support, self-soothing, and self-evaluation. Related obstacles in stress management efforts lie in work ineffectiveness, time inefficiencies, information vagueness, and individual characteristics.
\end{abstract}

Tujuan penelitian ini adalah untuk menggambarkan faktor penyebab, upaya penanggulangan, serta hambatan dalam menanggulangi stres kerja di masa pandemi Covid-19 pada Karyawan Mina Wisata Islami Tour And Travel Haji Umrah Surabaya. Penelitian ini menggunakan metode penelitian kualitatif dengan studi kasus sebagai jenis penelitian. Studi kasus digunakan untuk mengamati, mendeskripsikan, dan menemukan gambaran utuh dari fenomena yang berkenaan dengan stres kerja di masa pandemi Covid-19 pada karyawan Mina Wisata Islami Tour and Travel Haji Umrah, Surabaya. Teknik pengumpulan data yang digunakan untuk menggali informasi dari Mina Wisata Islami Tour and Travel Haji Umrah Surabaya adalah melalui wawancara, observasi dan dokumentasi. Hasil penelitian yang didapatkan peneliti di lapangan menggambarkan, bahwa Faktor penyebab stres kerja pada karyawan Mina Wisata Islami didominasi oleh perubahan kondisi dan ketidakjelasan informasi secara bersamaan, sehingga karyawan tidak memiliki kuasa atas hal tersebut. Adapun beberapa stressor (kondisi) lainnya yang dapat memicu timbulnya stres kerja bagi karyawan, yakni tuntutan kerja, tuntutan waktu, peranan ganda, feedback yang dirasa kurang setelah ketika melaksanakan pekerjaan, kondisi lingkungan kerja, dan wewenang yang tidak tercukupi untuk melaksanakan tanggung jawab. Terkait upaya penanggulangan stres kerja karyawan menggunakan tiga metode, yakni dukungan sosial, penenangan diri, dan evaluasi diri. Terkait hambatan dalam upaya penanggulangan stres terletak pada ketidakefektifan kerja, ketidakefisienan waktu, ketidakjelasan informasi, dan karakteristik individu.

Copyright (C) 2022 Journal Of Islamic Management. All rights reserved.

\section{Editorial Office:}

Program Studi Manajemen Dakwah, Fakultas Dakwah dan Komunikasi, UIN Sunan Ampel Surabaya.

Jl. Ahmad Yani 117 Surabaya, Jawa Timur, Indonesia.

Email: jim@uinsby.ac.id 


\section{Pendahuluan}

Berita munculnya penyakit baru menggemparkan seluruh dunia, khususnya wilayah Indonesia pada bulan Desember tahun 2019. Penyakit tersebut disebabkan oleh virus yang menyebar di berbagai belahan dunia dan disebut dengan Corona (Covid-19). Virus Corona tergolong dalam jenis SARS-CoV-2 dan terdeteksi pertama kali di Kota Wuhan, China. ${ }^{1}$ Adanya Covid-19 telah dikonfirmasi Indonesia pada bulan Maret 2020 sampai sekarang. Terdapat beberapa kasus yang menjadi sorotan di masa pandemi, khususnya krisis kesehatan global.

Tidak hanya itu, pandemi Covid-19 mengakibatkan berbagai sektor perusahaan terhenti, khususnya pada bidang pariwisata terpaksa ditutup sementara. Perusahaan yang bergerak di bidang pariwisata dengan penawaran jasa seperti Tour and Travel yang terfokus pada ibadah Haji dan Umrah juga sementara ditangguhkan sampai berakhirnya pandemi. Hal tersebut dikarenakan adanya pengeluaran kebijakan baru dari masing-masing negara.

Pemerintah Indonesia memutuskan untuk menunda pemberangkatan seluruh jamaah haji serta umrah secara resmi melalui KMA (Keputusan Menteri Agama) Nomor 494, Tahun 2020. Keputusan ini diberlakukan guna menjaga kesehatan dan keselamatan calon jamaah serta sebagai perlindungan Warga Negara Indonesia. ${ }^{2}$ Sehingga, jamaah terpaksa menunggu kembali jadwal pemberangkatan ibadah Haji Umrah setelah pandemi mereda dan

\footnotetext{
${ }^{1}$ WHO, https://www.who.int/healthtopics/coronavirus\#tab=tab_1, diakses melalui web pada tanggal 20 Juli 2021, pukul 09.00 WIB

${ }^{2}$ Kemkes RI Pusat Kesehatan Haji,

https://puskeshaji.kemkes.go.id/berita/2020/11/12/

ber-haji-dan-ber-umrah-di-masa-pandemi-covid-

19, diakses melalui web pada tanggal 20 Juli 2021, pukul 23.14 WIB

${ }^{3} \mathrm{Rr}$. Ayu Widianingsih, dkk, "Tantangan

Organisasi dalam Mempertahankan Kinerja

Karyawan Selama Pandemi Covid-19 di
}

pemerintah telah mengizinkan serta membuka seluruh akses untuk menuju ke Arab Saudi.

Perusahaan telah mengatasi segala kebijakan pemerintah tersebut melalui bermacam-macam upaya. Pertama, membagi aktivitas kerja karyawan. Kedua, mempekerjakan karyawan dari rumah (work from home) dengan memanfaatkan platform media sosial yang ada. Ketiga, bahkan dengan merumahkan atau memberhentikan karyawan. Akan tetapi, perusahaan yang masih beroperasi dan mempekerjakan karyawan dipaksa untuk bisa menyesuaikan diri di masa pandemi. Selain itu, seluruh karyawan dianjurkan harus selalu waspada dalam bekerja. ${ }^{3}$

Beragam tuntutan sebagai bentuk kewaspadaan tersebut justru dapat menambah kekhawatiran para karyawan, sehingga dapat menimbulkan stres dalam bekerja. Stres kerja dapat memberikan dampak yang buruk terhadap perusahaan, karena berkenaan dengan aspek kesehatan dan kinerja para karyawan. Adanya pandemi Covid-19 menyebabkan produktivitas, efektivitas dan efisiensi kerja cenderung menurun. ${ }^{4}$

Maka dari itu, para karyawan yang bekerja pada biro travel Haji dan Umrah mengalami banyak kecemasan. Pertama, cemas akan kesehatan diri sendiri. Kedua, khawatir akan kebijakan pemerintah dan perusahaan dalam jangka waktu kedepan. Ketiga, bertambahnya jumlah karyawan yang dirumahkan. Keempat, menghambat segala aktivitas yang dapat menurunkan efektivitas dan efisiensi kinerja. ${ }^{5}$ Kelima,

Indonesia", Al Tijarah (Vol. 6, No. 3, Desember 2020), hlm. 195-197

${ }^{4}$ Amelia Eka Safitri dan Alini Gilang, "Pengaruh

Stres Kerja Terhadap Produktivitas Kerja

Karyawan Pada PT.Telkom Witel Bekasi”, Jurnal Ecodemica (Vol. 3, No. 2, September 2019), hlm. 178

${ }^{5}$ Rismayanti Rasdam, dkk, "Analisis Pengaruh Lingkungan Kerja, Kompensasi, dan Stress Kerja Terhadap Semangat Kerja dan Dampaknya Terhadap Kinerja Karyawan", Hasanuddin Journal of Applied Business and 
merasa bosan dan penat dengan pekerjaan, karena tidak bisa berkomunikasi secara leluasa dengan rekan kerja maupun konsumen. ${ }^{6} \quad$ Berbagai kecemasan karyawan tersebut, kemudian menjadi beban pikiran yang berlebih, sehingga dapat menimbulkan stres kerja.

Mangkunegara menyatakan, bahwa stres kerja disebabkan oleh banyaknya tanggungan pekerjaan, pengawasan kerja tidak berlangsung dengan baik, padatnya waktu dalam bekerja, lingkungan kerja yang tidak mendukung, adanya permasalahan kerja dan perbedaan penilaian antara pimpinan dengan karyawan. ${ }^{7}$ Stres kerja dapat berdampak baik dan buruk bagi seorang karyawan. Dampak yang baik dari stres kerja diantaranya adalah dapat memberi motivasi personal, kemauan untuk bekerja secara maksimal, dan meningkatkan pola pikir mengenai kehidupan yang lebih baik.

Akan tetapi, stres kerja juga dapat memberikan banyak dampak yang buruk. Pertama, karyawan sering merasa cemas, khawatir, dan takut, sehingga dapat mengakibatkan depresi. Kedua, karyawan akan mengalami kecelakaan kerja berupa perilaku impulsif dan emosional yang berlebihan. Ketiga, berkurangnya rasa komitmen dan loyalitas pada perusahaan, sehingga dapat mengganggu kinerja sehari-hari. ${ }^{8}$

Pada kondisi seperti sekarang ini, stres tergolong dalam tekanan yang cukup tinggi dalam bekerja. Hal ini dikarenakan oleh informasi kasus Covid-19 yang semakin bertambah, akan mendorong pemerintah untuk terus melakukan evaluasi terhadap

Entrepreneurship/HJABE (Vol. 1, No. 4, Oktober 2018), hlm. 96-106

${ }^{6}$ Muhammad Rasyid, "Analisis Hubungan Lingkungan Kerja dan Stress Kerja Terhadap Kinerja Karyawan Pada PT. Medan Sugar Industri", Majalah Ilmiah Politeknik Mandiri Bina Prestasi (Vol. 6, No.2, Desember 2017), hlm. 240247 kebijakan-kebijakan baru seperti PSBB, New Normal sampai pada PPKM. ${ }^{9}$

PPKM masih diberlakukan sampai saat ini. Selain itu, PPKM juga terbagi menjadi beberapa level, yakni level 1-4. Akibatnya, karyawan akan sulit bertemu dan berkomunikasi dengan rekan kerja maupun konsumen, karena banyaknya kebijakan yang diterapkan oleh pemerintah. Sehingga, hal tersebut tentu akan menyebabkan banyaknya karyawan yang merasa tidak nyaman akan pekerjaan yang dilakukan secara virtual dan monoton dari rumah (WFH). Berbagai perusahaan telah mempraktikkan kebijakan untuk bekerja dari rumah. Salah satunya pada perusahaan jasa seperti Mina Wisata Tour and Travel Haji dan Umrah Surabaya.

Berdasarkan kondisi saat ini, kebijakan pemerintah telah diperlonggar. Hal ini dikarenakan masyarakat yang patuh dalam menjalani perintah untuk menjaga kesehatan masing-masing, sehingga kasus penyebaran virus dapat berangsur turun dan keadaan mulai membaik. Selain itu, pemerintah menyelenggarakan program vaksinasi sebagai upaya dalam mencegah Covid-19.

Penyelenggaraan vaksinasi telah berjalan cukup baik. Beberapa hal tersebut dapat dibuktikan dengan turunnya level PPKM di berbagai provinsi maupun kota. Akibatnya, situasi pun kian berubah serta dapat dirasakan dan dilihat oleh berbagai kalangan, seperti mulai dibukanya tempat umum yakni mall-mall besar, tempat wisata, dan travel termasuk pada perjalanan Haji dan Umrah.

Dalam beroperasi, Mina Wisata menerapkan berbagai ketentuan yang harus

\footnotetext{
${ }^{7}$ A. A. Anwar Prabu Mangkunegara, Manajemen Sumber Daya Manusia Perusahaan (Bandung: PT Remaja Rosdakarya, 2013), hlm. 157

${ }^{8}$ Gibson, Ivancevich, dan Donnelly, Organisasi (Jakarta: Binarupa Aksara, 1996) hlm. 339-363

${ }^{9}$ Gani Apriningtyas Budiyati dan Eka Oktavianto, "Stress dan Resiliensi Remaja di Masa Pandemi Covid-19", Husada Mahakam : Jurnal Kesehatan (Vol. 10, No. 2, November 2020), hlm. 11-18
} 
dipenuhi serta ditaati pada setiap kegiatannya. Ketentuan tersebut berlaku bagi jajaran staff ketika bekerja dan jama'ah yang memiliki keinginan untuk melaksanakan Ibadah Haji dan Umrah. Mina Wisata juga akan tetap memantau perkembangan informasi situasi serta kondisi yang akan semakin diperbaharui oleh pemerintah. Hal tersebut dikarenakan masa pandemi yang masih aktif di Indonesia dan Negara lain.

Kondisi yang masih dinamis dan tidak dapat dipastikan dengan jelas seperti sekarang ini, akan menambah beban pada seluruh jajaran staff atau karyawan Mina Wisata Islami Tour and Travel Haji Umrah Surabaya. Beban tersebut berasal dari adanya tuntutan untuk menyesuaikan diri kembali pada kondisi yang sedang berlangsung. Kemudian, beban yang dirasa berat dan semakin bertambah akan memicu timbulnya stres kerja.

Kebijakan Pemerintah yang masih simpang siur mengenai keberangkatan Ibadah Haji dan Umrah, juga menyebabkan banyaknya calon jama'ah yang mempertimbangkan kembali dalam mendaftar dan mengurungkan niatnya untuk beribadah ke Tanah Suci. Terlebih di masa Pandemi seperti sekarang ini, terdapat beberapa faktor yang menyebabkan calon jama'ah yang sudah mendaftar dan sempat tertunda keberangkatannya dapat membatalkan Ibadah Haji dan Umrah.

Hal tersebut tentunya tetap dilayani dan ditangani dengan baik oleh karyawan Mina Wisata Islami Tour and Travel Haji Umrah. Selain itu, perusahaan tetap akan me-refund atau mengembalikan sejumlah biaya yang telah dibayarkan calon jama'ah untuk keberangkatan Ibadah Umrah maupun Haji. Akan tetapi, hal ini melewati serangkaian proses yang menyebabkan

\footnotetext{
${ }^{10}$ Hasil observasi di Kantor Mina Wisata Islami Tour and Travel Haji Umrah saat program PPL, pada tanggal 29 Oktober 2021, 10.10 WIB

${ }^{11}$ Panji Anoraga, Psikologi Kerja (Jakarta: Rineka Cipta, 2014), hlm. 108
}

karyawan masih menangani berbagai pekerjaan di masa pandemi. ${ }^{10}$

Mengingat segala kegiatan dan tuntutan yang masih perlu di-handle serta sedang terjadi di masa pandemi covid-19 pada karyawan Mina Wisata Islami Tour and Travel Surabaya, maka hal ini telah menarik perhatian peneliti untuk mengkaji fenomena tersebut. Fokus penelitian ini adalah faktor penyebab stres kerja di masa pandemi covid-19 yang terjadi pada karyawan Mina Wisata Islami Tour and Travel Surabaya. Selain itu, peneliti juga ingin mendeskripsikan upaya dan hambatan dalam penanggulangan stres kerja di masa pandemi pada karyawan Mina Wisata Islami Tour and Travel Surabaya.

\section{Kajian Pustaka}

\section{Stres Kerja}

Stres adalah salah satu masalah yang berkaitan dengan kondisi psikis yang dialami oleh karyawan ketika bekerja. Anoraga mendefinisikan, bahwa stres merupakan bentuk respon terhadap siklus perubahan lingkugan. Perubahan tersebut memunculkan rasa tidak nyaman, sehingga karyawan akan menghadapi konflik internal yang berakibat pada kondisi fisik maupun jiwa. ${ }^{11}$

Apabila kayawan tidak bisa beradaptasi dengan lingkungan kerja, maka ia akan merasa tertekan dalam melakukan setiap pekerjaan yang diberikan oleh perusahaan. Hal ini akan berakibat pada kinerja karyawan, karena pekerjaan yang dilakukan menjadi tidak optimal. Sehingga memberi kesan negatif pada lingkungan sosial, perusahaan, serta memberi hasil yang tidak maksimal. ${ }^{12}$

Stres dapat digolongkan menjadi dua macam, yakni distress dan eustress. Distress merupakan stres yang dapat

\footnotetext{
${ }^{12}$ Subhan Ajrin Sudirman, "Stres Kerja dengan Keharmonisan Keluarga Pada Karyawan", Jurnal Al-Qalb (Vol. 10, No. 1, Maret 2018), hlm. 79-80
} 
mengarah pada hal negatif. Sedangkan, eustress merupakan stres yang mengarah pada hal positif. ${ }^{13}$ Stres dipandang sebagai kondisi yang negatif serta berkaitan dengan masalah jiwa dan raga. Hal tersebut dikarenakan adanya perbedaan situasi dengan perilaku, keadaan fisik maupun psikis, serta lingkungan sosial. ${ }^{14}$ Selain itu, stres juga menjadi masalah yang berbahaya, apabila ketentuan kerja tidak sebanding dengan sumber daya, kemampuan serta keinginan individu. ${ }^{15}$

Stres dapat ditanggulangi melalui berbagai upaya. Upaya penanggulangan stres merupakan serangkaian cara untuk mengatasi serta mengelola stres dengan baik, agar terhindar dari dampak negatif (distres). Hal tersebut juga dapat ditangani dengan manajemen stres. Robbins mendefinisikan, bahwa manajemen stres adalah suatu kegiatan yang bertujuan untuk menstabilkan kondisi psikis dan mengembangkan sikap yang positif, sehingga memudahkan seseorang dalam bersosialisasi dan berkomunikasi dengan baik. ${ }^{16}$

Oleh karena itu, jika seseorang dapat me-manage stres dengan baik, maka ia cenderung mengarahkan hal tersebut pada kegiatan yang positif serta optimis dalam mengatasi segala tekanan yang diberikan dalam bekerja. Namun, apabila seorang individu tidak dapat me-manage stres dengan baik, maka ia akan mengalami kesulitan secara terus menerus dalam menghadapi segala tuntutan atau tekanan.

Menurut Selye yang dikutip oleh Munandar, stres dapat diarahkan dan menjadi motivasi yang positif untuk

\footnotetext{
${ }^{13}$ Lumban Gaol, “Teori Stres: Stimulus, Respons, dan Transaksional”, Buletin Psikologi (Vol. 24, No. 1, 2016), hlm. 7

${ }^{14}$ Ressy Julianti Sibuea, "Pengaruh Stres dan Konflik Terhadap Kinerja Pegawai Pada PT PLN (Persero) P3B Sumatera UPT Pematangsiantar", Jurnal SULTANIST (Vol. 6, No. 1, Juni 2017)

15 Juli Ardani, dkk., "Analisis Faktor-Faktor Penyebab Stres Kerja Pada StafRekam Medis di Rumah Sakit Umum Daerah Kota Mataram”,
}

mewujudkan prestasi kerja. ${ }^{17}$ Robbins menyebutkan, bahwa terdapat lima indikator stres kerja ${ }^{18}$, yakni :

a) Keharusan memenuhi hak dan kewajiban untuk menyelesaikan tugas. Hal tersebut meliputi segala hal yang berkenaan dengan peran selama bekerja. Apabila seorang karyawan tidak menyukai perannya di perusahaan, maka ia akan cenderung mengabaikan tugas-tugasnya. Kemudian, tugas tersebut akan terus bertambah dan akan menjadi beban baginya. Sehingga, hal tersebut akan berakibat pada kondisi fisik maupun psikisnya.

b) Menyadari dan menjalani kedudukan yang telah diberikan dengan sebaikbaiknya. Jika seorang karyawan tidak mampu untuk bekerja sesuai dengan perannya, maka ia tidak akan bekerja secara optimal dan hasilnya tidak akan maksimal.

c) Hubungan sosial, yang terjalin antar karyawan. Apabila antar karyawan tidak memiliki hubungan yang baik, maka dapat dipastikan sering terjadi konflik ketika bekerja. Sehingga, hal tersebut akan mendorong timbulnya stres kerja, karena lingkungan yang tidak harmonis.

d) Struktur kepengurusan atau organisasi yang kurang jelas mengenai kedudukan, peran, dan lain sebagainya. Kemudian, karyawan akan lalai dan tidak bertanggung jawab terhadap perannya. Hal tersebut dapat terjadi karena, ia tidak faham

\footnotetext{
Jurnal Magister Manajemen Universitas Mataram (Vol. 6, No. 1, Maret 2017), hlm. 3

${ }^{16}$ Eka Putri Wahyuningtiyas S, dkk, "Hubungan Manajemen Stres dengan Perilaku Prokrastinasi Akademik Pada Mahasiswa yang Sedang Menyusun Skripsi”, Jurnal RAP UNP (Vol. 10, No. 1, Mei 2019), hlm. 31-32

${ }^{17}$ Ashar Sunyoto Munandar, Psikologi Industri dan Organisasi (Jakarta: UI Press, 2008), hlm. 374

${ }^{18}$ Stephen P. Robbins, Prinsip-Prinsip Organisasi (Jakarta: PT Erlangga, 2006), hlm. 796-797
} 
tentang tugas dan kewajiban yang harus dikerjakan.

e) Gaya kepemimpinan. Pemimpin akan menjadi panutan bagi tiap karyawan di perusahaan. Apabila seorang pemimpin memiliki karakter yang buruk, maka karyawan tidak akan merasa nyaman dan betah ketika melakukan pekerjaan. Kemudian, hanya akan terjadi suasana yang canggung antar pimpinan dan karyawan. Sehingga, hal tersebut akan memicu timbulnya stres dalam bekerja.

\section{Faktor Penyebab Stres Kerja}

Menurut Anwar Prabu yang dikutip oleh Maria menyebutkan, bahwa stres kerja disebabkan oleh berbagai faktor. Pertama, beban yang sangat berat. Kedua, tuntutan waktu. Ketiga, manajemen pengawasan yang tidak optimal. Keempat, lingkungan kerja yang tidak mendukung. Kelima, fungsi controlling tidak berjalan dengan baik. Keenam, adanya konflik dalam bekerja. Ketujuh, adanya kesenjangan antara pemimpin dan karyawan. ${ }^{19}$ Handoko mendefinisikan kondisi tersebut sebagai stresors. Stresors dapat terbagi menjadi dua ${ }^{20}$ yaitu:

a. Di dalam ruang lingkup pekerjaan (On The Job)

Stres On The Job disebabkan oleh berbagai faktor, diantaranya adalah:

1. Tuntutan Pekerjaan yang meliputi suatu fokus yang berkenaan dengan

\footnotetext{
${ }^{19}$ Maria Tiahohu Sinaga dan HP Sunardi,

"Analisis Pengaruh Stres Kerja Terhadap Prestasi

Kerja Karyawan Pada PT Bardie Puritama", Jurnal

Ilmiah Manajemen Bisnis (Vol. 13, No. 2,

November 2013), hlm. 78

${ }^{20}$ T. Hani Handoko, Manajemen Edisi Kedua

(Yogyakarta: BPFE-Yogyakarta, 2011), hlm. 200

${ }^{21}$ Andriani Nugraha dan Sylvia Diana Purba,

"Tuntutan Pekerjaan dan Stresm Kerja Sebagai

Variabel Penentu Turnover Intention", Jurnal

Manajemen dan Pemasaran Jasa (Vol. 10, No. 1,

Maret 2017), hlm. 51

${ }^{22}$ Abdul Jalil, "Pengaruh Beban Kerja, Stres Kerja dan Lingkungan Kerja Terhadap Kinerja Guru Madrasah Aliyah Negeri 2 Kota Palu”, Jurnal Ilmu Perbankan dan Keuangan Islam (Vol.1, No. 2, Tahun 2019), hlm. 118
}

pekerjaan, yakni beban kerja, cara kerja, situasi serta kondisi yang dirasakan oleh karyawan ketika bekerja. ${ }^{21}$

2. Tuntutan waktu kerja secara tidak langsung akan menambah beban kerja. Dalam hal tersebut, karyawan dituntut untuk mengerjakan suatu tugas yang diberikan dalam waktu yang telah ditentukan. ${ }^{22}$

3. Feedback yang dirasa kurang ketika melaksanakan pekerjaan. Dalam hal feedback (umpan balik) dengan pelanggan, diartikan sebagai bentuk komunikasi yang harus diterima karyawan dalam bekerja. ${ }^{23}$

4. Memegang peranan ganda dalam perusahaan membutuhkan usaha yang maksimal, agar dapat meminimalisir atau mencegah timbulnya konflik dalam bekerja. $^{24}$

5. Kondisi lingkungan kerja yang tidak dapat diperkirakan akan mendorong timbulnya ketidaknyamanan dalam bekerja. $^{25}$

6. Wewenang yang tidak tercukupi untuk melaksanakan tanggung jawab.

Seorang karyawan hanya memiliki kekuasaan dan hak untuk memberikan informasi, data, dan saran-saran yang sesuai dengan prosedur perusahaan. Hal tersebut dilakukan, agar masing-masing karyawan dapat bekerja efektif dalam mencapai tujuan perusahaan. ${ }^{26}$

\footnotetext{
${ }^{23}$ Moh Oktaviannur, "Budaya Organisasi, Fleksibilitas Kerja, dan Feedback Terhadap Prestasi Kerja Transportasi GOJEK di Palembang", Jurnal Sains Sosio Humaniora (Vol. 4, No. 2, Desember 2020), hlm. 369-370 ${ }^{24}$ Arie Gunawan HZ, dkk., "Pengaruh Konflik Peran Ganda Terhadap Stres Kerja Pada Karyawan Wanita di PT. South Suco Makassar", Indonesian Journal of Business and Management (Vol. 3 , No. 1, Desember 2020), hlm. 140

${ }^{25}$ Faris Lazwar Irkhami, "Faktor yang

Berhubungan dengan Stres Kerja Pada Penyelam di PT. X", The Indonesian Journal of Occupational Safety and Health (Vol. 4, No. 1, Jan-Jun 2015), hlm. 54-63

${ }^{26}$ Raja Saul Marto Hendry, "Pengaruh

Kepemimpinan, Wewenang Jabatan, dan Iklim
} 
b. Diluar ruang lingkup pekerjaan (Off The Job)

Stres Off The Job juga diakibatkan oleh berbagai hal, yakni:

1. Masalah Ekonomi

2. Masalah pribadi yang menyangkut fisik maupun psikis

3. Masalah keluarga

\section{Gejala Stres Kerja}

Robbins dan Judge
menyebutkan, bahwa terdapat
beberapa hal guna mengetahui gejala stres kerja yang dialami oleh masingmasing individu ${ }^{27}$, antara lain:

1. Gejala secara fisik dapat dirasakan dan dilihat perubahannya pada peningkatan denyut jantung, nadi, tensi darah, serta siklus pernafasan. Kemudian, menimbulkan efek parah, yakni sakit kepala, serangan jantung, sampai pada penyakit kronis lainnya.

2. Gejala dari segi psikis dapat dilihat dari perubahan pola pikir dan perasaan yang meliputi perasaan cemas, sedih, marah, kecewa, khawatir, takut, dan sebagainya. Sedangkan perubahan pada pola pikir meliputi turunnya konsentrasi, pelupa, sulit untuk berkomunikasi dengan baik, kurangnya rasa percaya diri, dan sebagainya.

3. Gejala dari segi sikap dapat dilihat dari tidak adanya rasa semangat, kurangnya kreatifitas dan inovasi, jumlah ketidakhadiran yang semakin tinggi, turnover intention, mengkonsumsi obat-obatan terlarang, dan sebagainya.

Selain itu, stres kerja berakibat pada berbagai hal melalui sepuluh gejala $^{28}$, diantaranya adalah Pertama,

Organisasi Terhadap Kinerja Karyawan Pada Dinas PUPR Kabupaten Labuhanbatu Utara”, Jurnal Informatika : Fakultas Sains dan Teknologi Universitas Labuhanbatu (Vol. 5, No.2, Mei 2017), hlm. 54 menurunnya kondisi kesehatan secara fisik dan menyeluruh. Kedua, mencari tempat untuk menghindari kewajiban dan melakukan kegiatan yang cenderung negatif. Ketiga, mudah marah. Keempat, menilai dan merasa martabatnya rendah. Kelima, selalu merasa kecewa dan tidak puas terhadap sesuatu yang telah dikerjakan. Keenam, rasa bersyukur yang kurang. Ketujuh, menurunnnya dorongan untuk melakukan kinerja dan hasil kerja yang baik. Kedelapan, kurangnya komitmen pada perusahaan. Kesembilan, berperilaku tidak sopan dan banyak menuntut pada atasan. Kesepuluh, mudah putus asa.

\section{Proses Terjadinya Stres Kerja}

Menurut Hans yang dikutip oleh Munandar menjelaskan, bahwa terdapat serangkaian proses timbulnya penyakit akibat stres. Hans memperhatikan adanya masalah atau kesulitan yang terjadi pada masingmasing individu, ketika sedang menyesuaikan, mengenali, dan menghadapi lingkungan beserta tuntutannya. Ia menyimpulkan, bahwa masing-masing individu pasti akan mengalami tiga fase dalam menghadapi masalah tersebut.

Pertama, Hans menyebut fase ini sebagai pertanda bahaya. Maksudnya adalah seorang individu dituntut, agar selalu mampu untuk beradaptasi segala ketentuan dan lingkungan perusahaan. Ia akan merasakan dan menyadari, bahwa hal tersebut juga merupakan ancaman yang berlanjut. Namun, perasaan tersebut tidak berlangsung lama dan akan memasuki fase selanjutnya. Kemudian tahap

\footnotetext{
${ }^{27}$ Stephen P. Robbins dan Timothy A. Judge, Perilaku Organisasi (Organizational Behavior) Edisi 16 (Jakarta: Salemba Empat, 2015), hlm. 434 ${ }^{28}$ Wiari Utaminingtias, dkk., "Coping Stres Karyawan dalam Menghadapi Stres Kerja", PROSIDING KS: RISET \& PKM (Vol. 3, No.2), hlm. 95
} 
Kedua, seorang individu akan berjuang untuk melawan dan menjalani ketentuan yang berlaku di perusahaan.

Ketiga, fase yang berada pada titik paling rendah dari masing-masing individu. Fase tersebut disebut juga sebagai titik lelah. Apabila tuntutan dari perusahaan semakin bertambah, maka masing-masing individu atau karyawan akan semakin terbebani. Sehingga, stres akan mudah timbul pada kondisi seperti ini. Namun, apabila kondisi fisik secara keseluruhan cukup stabil, maka hal tersebut tidak akan menyebabkan timbulnya penyakit yang serius. ${ }^{29}$

\section{Dampak Stres Kerja}

Stres kerja dikatakan dapat memberi pengaruh yang cukup signifikan pada kinerja karyawan. Stres membawa dampak yang negatif pada kesejahteraan diri sendiri maupun kesejahteraan bersama. Karyawan cenderung mengalami stres yang berlebih pada generasi sekarang dan yang akan mendatang, karena ia bekerja dibawah tekanan, diatur oleh ketentuan yang seringkali berubah, kondisi yang dinamis dan tidak dapat dipastikan, serta adanya kecemasan mengenai pemberhentian sistem kontrak karyawan. ${ }^{30}$

Stres kerja dapat membawa dampak yang negatif bagi pribadi seorang karyawan maupun perusahaan. Setiap perilaku dan kegiatan yang dilakukan oleh karyawan, akan berimbas pada perusahaan. Selain itu, apabila karyawan memiliki karakteristik yang buruk dalam sikap, perilaku, maupun pekerjaan, maka

${ }^{29}$ Ashar Sunyoto Munandar, Psikologi Industri dan Organisasi (Jakarta: UI Press, 2001), hlm. 372

${ }^{30}$ Giszka Gita Maserati dan Herison Pandapotan Purba, "Pengaruh Stres Kerja dan Coronavirus Anxiety terhadap Mental Well-Being pada Generasi Milenial", Buletin Riset Psikologi dan nama dan citra (image) perusahaan akan buruk di mata konsumen.

Menurut Jacinta dalam Wiari mengungkapkan, bahwa stres dapat membawa dampak yang negatif dan merugikan perusahaan $^{31}$ diantaranya adalah sebagai berikut:

a.) Menghambat dan menggangu sistem manajemen operasional pada perusahaan

b.) Menurunnya tingkat efektivitas dan efisiensi kerja

c.) Menurunnya tingkat kreatifitas

d.) Menurunnya produktivitas perusahaan

e.) Meningkatnya jumlah absensi

f.) Mengalami kerugian secara finansial, sehingga berdampak pada laba yang didapatkan. Hal tersebut dikarenakan jumlah pengeluaran tidak seimbang dengan pemasukan. Sehingga, perusahaan merasa tidak mampu untuk memberi insentif, upah karyawan, dan lain sebagainya.

Maka dari itu, dapat disimpulkan bahwa stres kerja juga memberi dampak pada perusahaan dan mengalami kerugian yang cukup besar. Akan tetapi, perusahaan selalu memiliki jalan keluarnya masing-masing untuk mengatasi semua masalah yang sedang terjadi. Hal tersebut dikarenakan perusahaan telah menganggap karyawan sebagai aset utama dan berharga.

\section{Upaya Penanggulangan Stres Kerja}

Menurut Mangkunegara dalam Jurnal Bisnis Administrasi yang disusun oleh Shandy dan Neni menyebutkan,

Kesehatan Mental (BRPKM) (Vol. 1, No. 1, 2021), hlm. 190-191

${ }^{31}$ Wiari Utaminingtias, dkk., "Coping Stres Karyawan dalam Menghadapi Stres Kerja", PROSIDING KS: RISET \& PKM (Vol. 3, No.2), hlm. 95 
bahwa stres kerja dapat ditanggulangi melalui empat metode ${ }^{32}$, yakni :

a. Melalui metode dukungan sosial, seperti pemberian motivasi, reward, dan insentif dalam bekerja. Hal tersebut bertujuan untuk menciptakan kepuasan kerja pada karyawan setelah meraih pencapaian tujuan perusahaan.

b. Melalui metode penenangan diri, seperti memfokuskan pikiran pada hal yang positif, meregangkan badan, dan menstabilkan perasaan.

c. Melalui metode biofeedback yang dibimbing oleh dokter, pskiater, dan sebagainya. Pada metode ini, seorang individu atau karyawan dapat melakukan konsultasi serta pengobatan dengan tenaga spesialis atau profesional sesuai dengan permasalahan yang dialami. Sehingga, ia dapat mengatasi dan melalui proses penyembuhan stres dengan baik.

d. Melalui metode evaluasi diri sebelum, selama, dan sesudah melakukan pekerjaan.

\section{Hambatan Penanggulangan Stres Kerja}

Siagian mengkategorikan sikap manusia menjadi dua kelompok dalam mengendalikan hidupnya. Pertama, seseorang yang bersikap optimis dan percaya, bahwa takdir ditentukan oleh diri sendiri. Apabila seorang karyawan memiliki sikap selalu optimis dan percaya pada dirinya sendiri, maka ia mampu untuk menghadapi segala tekanan. Selain itu, ia juga lebih mampu dalam menghadapi dan

\footnotetext{
${ }^{32}$ Shandy E. Santayana dan Neni Triastuti,

"Analisis Stres Kerja Pada Karyawan PT.

Perkebunan Nusantara IV Kebun Bah Jambi",

Jurnal Bisnis Administrasi (Vol. 2, No. 2, 2013), hlm. 50

${ }^{33}$ Sondang P Siagian, Teori Pengembangan Organisasi, (Jakarta: Bumi Aksara, 2000), hlm. 147-148
}

mengatasi stres sebagai akibat dari tekanan tersebut.

Kedua, seseorang yang beranggapan bahwa ia hanya sebagai pemeran dalam hidupnya dan pihak lain yang dapat mengatur peran yang akan dijalankan. Apabila seorang karyawan memiliki sikap seperti ini, maka ia akan cenderung menggantungkan hidupnya pada orang lain dan tidak dapat mengatasi masalahnya sendiri. Selain itu, jika hal tersebut sudah terjadi dan menimbulkan stres, maka ia juga tidak akan bisa menghadapi dan mengatasinya dengan baik. ${ }^{33}$ Menurut Pergament dalam skripsi yang ditulis oleh Zalfa mengungkapkan, bahwa hambatan dalam penanggulangan stres merupakan suatu sumber yang dapat membawa pengaruh pada upaya yang telah dilakukan dalam menanggulangi stres. ${ }^{34}$

Hambatan dalam penanggulangan stres dapat berasal dari teknik yang diambil dalam memecahkan suatu permasalahan. Apabila seorang karyawan hanya meyakini dan menggunakan teknik emotion focused coping dan religious focused coping dalam menanggulangi stres, maka ia tidak akan bisa memecahkan masalah dengan baik dan cepat, sehingga permasalahan tersebut akan mudah terulang kembali di masa yang akan datang. ${ }^{35}$

Emotion focused coping merupakan suatu strategi yang terfokus pada usaha untuk mengurangi respon emosional dan menghindar dari kondisi

\footnotetext{
${ }^{34}$ Zalfa K, "Hubungan Antara Tingkat Religiusitas dengan Strategi Coping pada Santri Pondok Pesantren Nurul Huda Mergosono Malang), Skripsi (Malang: Fakultas Psikologi, UIN Maulana Malik Ibrahim, 2009)

${ }^{35}$ Lathifah Hanum, dkk, "Penerapan Manajemen Stres Berkelompok dalam Menurunkan Stres pada Lanjut Usia Berpenyakit Kronis", Jurnal Psikologi (Vol. 43, No. 1, 2016), hlm. 48
} 
yang dapat memicu stres. ${ }^{36}$ Sedangkan, religious focused coping merupakan dukungan secara spiritual untuk mengatasi stres kehidupan dan menyesuaikan diri dengan kondisi yang ada. ${ }^{37}$

\section{Stres Kerja dalam Perspektif Islam}

Adanya suatu ketentuan serta tuntutan perusahaan ditujukan pada karyawan guna mencapai tujuan dan hasil kerja yang maksimal, sehingga hal tersebut memerlukan kesiapan dan pencegahan untuk menghadapi situasi yang berujung pada timbulnya stres. Kemudian, stres akan mengakibatkan ganggguan pada kesehatan mental dan fisik karyawan. Terdapat satu hal yang dapat meminimalisir munculnya stres kerja pada karyawan, yakni dengan proses resiliensi.

Resiliensi adalah suatu kegiatan yang berfungsi untuk menangkal dampak negatif yang akan terjadi pada kehidupan saat ini maupun yang akan mendatang. Hal ini dapat dilihat dari seorang individu yang berhasil melalui segala rintangan, cobaan, dan tuntutan dalam bekerja, walaupun pernah terjadi peristiwa buruk pada situasi tersebut. Oleh karena itu, proses resiliensi membutuhkan adanya suatu dorongan berupa motivasi yang akan membawa pada hal yang positif.

Menurut pandangan (perspektif) Islam, proses resiliensi untuk menghadapi stres dapat berjalan dengan baik, apabila individu memiliki nilai spiritualitas yang tinggi. Spiritualitas dalam aspek tersebut diukur sebagai nilai keimanan dan ketakwaan seseorang untuk

${ }^{36}$ Syaiful Indra, dkk., "Emotion Focused Coping Dalam Mereduksi Kecemasan Pada Masa Pandemi Covid-19”, JUANG: Jurnal Wahana Konseling (Vol. 3, No. 2, September 2020), hlm. 103

${ }^{37}$ Muhana Sofiati Utami, "Religiusitas, Koping Religius, dan Kesejahteraan Subjektif", JURNAL PSIKOLOGI (Vol. 39, No. 1, JUNI 2012), hlm. 49 menjalankan ibadah. ${ }^{38}$ Salah satunya yakni, bekerja. Hal tersebut telah diperintahkan melalui firman Allah pada Qs. Al-Jumu'ah (62):10 yang berbunyi:

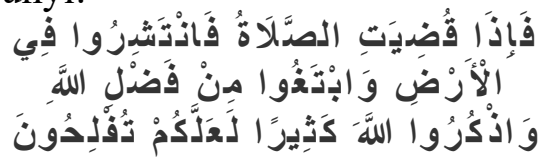

Artinya : Apabila shalat telah dilaksanakan, maka bertebaranlah kamu di bumi, carilah karunia Allah, dan ingatlah Allah banyakbanyak agar kamu beruntung.

Dari ayat tersebut, dapat dilihat dan dicerna bahwa bekerja merupakan suatu kegiatan yang diperintahkan langsung oleh Allah melalui AlQur'an. Selain itu, dalam buku tafsir ibnu katsir memaparkan, bahwa bekerja juga memberi manfaat bagi keberlangsungan hidup, seperti terciptanya komunikasi antar sesama manusia, mampu beradaptasi pada lingkungan di sekitar, dan sebagainya. ${ }^{39}$

Akan tetapi, berdasarkan fenomena yang terjadi, seorang karyawan akan mengalami banyak stres dalam bekerja. Hal tersebut dipicu oleh berbagai faktor diantaranya adalah merasa sulit dan tidak mampu menyesuaikan diri dengan kondisi serta lingkungan kerja, bekerja dibawah tekanan, banyaknya ketentuan dan tuntutan dalam bekerja, hubungan antar rekan kerja dan atasan tidak berlangsung harmonis, dan lain sebagainya.

Masing-masing individu pasti pernah merasakan ketidaksesuaian antara keinginan dengan kenyataan

\footnotetext{
${ }^{38}$ Muhammad Asrun dan Annisaa Miranty Nurendra, "Meningkatkan Resiliensi Masyarakat yang Terkena PHK di Masa Pandemi Menurut Perspektif Psikologi Islam", Motiva: Jurnal Psikologi (Vol. 4, No. 1, 2021), hlm. 33

${ }^{39}$ Abdullah bin Muhammad bin 'Abdurrahman bin Ishaq Alu Syaikh, Tafsir Ibnu Katsir Jilid 2 (Bogor: Pustaka Imam Asy-Syafi'i, 2007)
} 
yang dihadapi. Kemudian, hal tersebut akan menyebabkan timbulnya rasa kecewa, sedih, bahkan marah. Situasi seperti ini menggambarkan adanya masalah secara psikis, yaitu stres. ${ }^{40}$ Segala kenyataan yang dihadapi tersebut merupakan sebagian dari cobaan dari Allah dan telah disampaikan dalam Qs. Al-Baqarah (2):155 yang berbunyi :

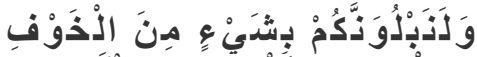

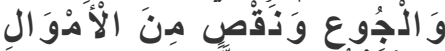

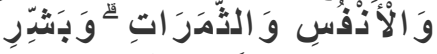

$$
\begin{aligned}
& \text { الصَّابِر يَنَ }
\end{aligned}
$$

Artinya : dan sungguh akan Kami berikan cobaan kepadamu, dengan sedikit ketakutan, kelaparan, kekurangan harta, jiwa dan buahbuahan. dan berikanlah berita gembira kepada orang-orang yang sabar.

Berdasarkan ayat tersebut, dapat disimpulkan bahwa Allah akan memberi ganjaran kepada setiap orang yang sabar dalam menghadapi segala tuntutan hidup. Ganjaran tersebut berupa segala keberkahan karunia beserta pahala yang akan didapatkan oleh seorang mukmin. ${ }^{41}$ Dalam Islam, stres merupakan keadaan yang harus dihadapi oleh manusia ketika ia merasa tidak nyaman akan suatu tuntutan pekerjaan. Islam telah memberikan petunjuk, bahwa segala tuntutan tersebut adalah bentuk ujian hidup di dunia. ${ }^{42}$ Selain itu, Allah juga memberi peringatan dalam firmannya,

\footnotetext{
${ }^{40}$ Sugianto, "Manajemen Stres dalam Perspektif Tasawuf”, Al-Idarah: Jurnal Kependidikan Islam (Vol. 8, No. 1, Juni 2018), hlm. 155-160

${ }^{41}$ Team Ahli Tafsir di Bawah Pengawasan Syaikh Shafiyyurrahman al-Mubarakfuri, Shahih Tafsir Ibnu Katsir Jilid 1 Cet. Ke-16 (Jakarta: Pustaka Ibnu Katsir, 2016), hlm. 516-518

${ }^{42}$ Baqiyatul Auladiyah, "Islam dan Stress Kerja", https://studiislamkomprehensif.blogspot.com/2016 /02/islam-dan-stress-kerja-baqiyatul.html, diakses
}

yakni Qs. Yusuf (12):87 yang berbunyi :

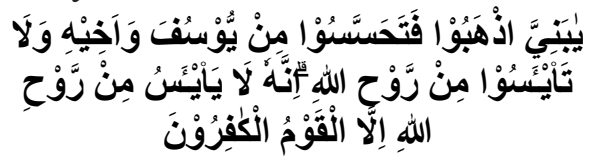

Artinya : Wahai anak-anakku! Pergilah kamu, carilah (berita) tentang Yusuf dan saudaranya dan jangan kamu berputus asa dari rahmat Allah. Sesungguhnya yang berputus asa dari rahmat Allah, hanyalah orang-orang yang kafir.

Dalam menghadapi cobaan, Allah melarang hamba-Nya untuk berputus asa. Allah memerintahkan untuk terus berusaha serta menyandarkan seluruh harapan kepada-Nya. ${ }^{43}$ Oleh karena itu, Allah senantiasa memberikan petunjuk dan jawaban atas segala persoalan yang terjadi dalam kitabNya yakni Al-Qur'an. Selain itu, AlQur'an juga menjadi pijakan bagi umat Muslim, agar hidupnya damai di dunia dan akhirat serta dapat menerima segala permasalahan yang terjadi dengan ikhlas. ${ }^{44} \mathrm{Hal}$ ini dituangkan dalam Qs. Thaha (20):2 yang berbunyi :

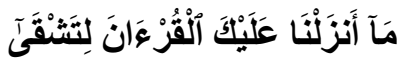

Artinya : Kami tidak menurunkan Al-Qur'an ini Kepadamu (Muhammad) agar Kamu menjadi susah.

Allah senantiasa memberi cobaan secara bertubi-tubi pada setiap makhluknya sebagai teguran untuk selalu mengingat-Nya. Dalam tafsir

melalui web pada tanggal 11 September 2021, pukul 11.54 WIB

${ }^{43}$ Tafsir Qs. Yusuf Ayat 87-88,

http://www.ibnukatsironline.com/2015/06/tafsirsurat-yusuf-ayat-87-88.html, diakses melalui web pada tangggal 30 September, pukul 16.45 WIB

${ }^{44}$ Muhammad Asrun dan Annisaa Miranty Nurendra, "Meningkatkan Resiliensi Masyarakat yang Terkena PHK di Masa Pandemi Menurut Perspektif Psikologi Islam”, Motiva: Jurnal Psikologi (Vol. 4, No. 1, 2021), hlm. 34 
Al-Jalalain menyebutkan, bahwa Allah menurunkan Al-Qur'an sebagai pertanda untuk memperingatkan Muhammad dan seluruh makhlukNya, agar memberi kesempatan beristirahat dari segala kegiatan yang menyebabkan letih dan penat. ${ }^{45}$

Islam juga mengajarkan, bahwa semakin bertambah dan susahnya setiap ujian, tekanan, atau cobaan yang dihadapi oleh seseorang, akan meninggikan derajatnya di hadapan Allah. Apabila seorang individu dapat menjalani segala tekanan yang diberikan dalam hidup, maka ia akan memperoleh ganjaran dari Allah baik di dunia maupun akhirat. ${ }^{46}$

\section{Metode Penelitian}

Penelitian ini menggunakan metode penelitian kualitatif dengan studi kasus (case study) sebagai jenis penelitian. Studi kasus digunakan untuk mengamati, mendeskripsikan, dan menemukan gambaran utuh dari fenomena yang berkenaan dengan stres kerja di masa pandemi Covid-19 pada karyawan Mina Wisata Islami Tour and Travel Haji Umrah, Surabaya.

Hal tersebut bertujuan untuk menganalisa secara langsung situasi dan kondisi yang terjadi di lapangan penelitian. Selain itu, data yang dikumpulkan juga bersifat akurat berdasarkan sumber yang telah dikumpulkan yaitu, informasi secara lisan (wawancara) dengan karyawan Mina Wisata Islami Tour and Travel Haji Umrah Surabaya. selain itu, peneliti juga menggunakan bukti berupa dokumen berupa sejarah dan struktur kepengurusan perusahaan dan menyajikannya dalam bentuk deskriptif. Kemudian, dari data-

\footnotetext{
${ }^{45}$ Jalaluddin As Suyuthi dan Jalaluddin Muhammad Ibnu Ahmad Al-Mahally, "Tafsir Jalalain", E-Book, hlm. 193

${ }^{46}$ Noor Izzati Mohd Zawawi, Fariza Md.Sham, dan A'dawiyah Ismail, "Stres Menurut Sarjana
}

data yang telah dikumpulkan tersebut akan dapat menggambarkan stres kerja di masa pandemi Covid-19 pada karyawan Mina Wisata Wisata Islami Tour and Travel Haji Umrah, Surabaya.

Jenis dan sumber data yang digunakan adalah data primer dan data sekunder. Proses pengumpulan data melalui teknik wawancara, teknik observasi dan teknik dokumentasi. Dalam proses validitas data, peneliti menggunakan triangulasi sumber. Triangulasi sumber adalah teknik yang dilakukan untuk mengecek kreadibilitas data melalui perbandingan data yang diterima dari beberapa sumber.

\section{Hasil dan Pembahasan}

Anoraga mendefinisikan, bahwa stres merupakan bentuk respon terhadap siklus perubahan lingkugan. Perubahan tersebut memunculkan rasa tidak nyaman, sehingga karyawan akan menghadapi konflik internal yang berakibat pada kondisi fisik maupun jiwa. ${ }^{47}$ Dalam hal ini, karyawan Mina Wisata Islami Tour and Travel Haji Umrah Surabaya menyadari dan mengalami adanya perbedaan ketika bekerja di masa pandemi covid-19. Pemaparan data wawancara diatas menunjukkan, bahwa tiap karyawan memiliki kekhawatiran dan kecemasan yang tidak terlepaskan selama bekerja di masa pandemi. Hal tersebut dikarenakan oleh kondisi pandemi yang menghambat seluruh kegiatan termasuk pembatalan keberangkatan jamaah umrah.

Di masa pandemi, Mina Wisata Islami Tour and Travel Haji Umrah Surabaya memutuskan untuk tetap beroperasi, kecuali pada saat PPKM darurat dan PSBB yang mengharuskan kantor tutup karena anjuran pemerintah. Namun, berdasarkan hasil observasi dan

Barat dan Islam", International Journal of Islamic Thought (Vol. 16, Desember 2019), hlm. 88-93

${ }^{47}$ Panji Anoraga, Psikologi Kerja (Jakarta: Rineka Cipta, 2014), hlm. 108 
beberapa pernyataan informan, seluruh karyawan tetap memiliki tugas dan tanggung jawab yang harus dijalankan untuk me-maintance dan menjalin hubungan yang baik dengan jamaah, meskipun hal tersebut dilakukan dari rumah. Pada saat itu juga kekhawatiran tersebut dapat terjadi karena ketidakjelasan informasi yang beredar di masa pandemi dan adanya jamaah yang mengurungkan niatnya untuk ibadah umrah. Maka dari itu, dapat disimpulkan bahwa, stres kerja dapat timbul karena ketidakjelasan informasi dan perubahan kondisi secara bersamaan, sehingga karyawan tidak memiliki kuasa atas hal tersebut.

Dengan demikian, peneliti dapat menganalisa bahwa hal ini sejalan dengan teori yang dikemukakan oleh Anoraga. Berdasarkan penelitian, stres kerja merupakan suatu respon yang timbul terhadap siklus perubahan lingkungan dan mengarah pada hal yang spesifik sesuai dengan kondisi yang ada. Perubahan lingkungan yang dimaksud adalah masa pandemi covid-19, sehingga hal ini dapat menimbulkan banyak perasaan khawatir hingga tidak nyaman yang ada dalam diri karyawan Mina Wisata Islami ketika bekerja.

Adapun tabel yang menjelaskan mengenai kegiatan dan perubahan kondisi kerja pada saat sebelum dan setelah pandemi. Kemudian, tabel ini juga dapat dilihat sebagai rujukan atas faktor-faktor yang menyebabkan adanya stres kerja mengenai tuntutan kerja, peran ganda, tuntutan waktu, dan kondisi lingkungan kerja yang tidak bisa diperkirakan pada masa pandemi covid-1948 :

\begin{tabular}{|l|l|}
\hline \multicolumn{3}{|c|}{ Sebelum Pandemi Covid-19 } \\
\hline Jumlah & 13 (Karyawan Tetap berjumlah 7 \\
Karyawan & Orang yang terbagi di dua kantor, \\
& yakni $\quad$ kantor kartini dan \\
\hline
\end{tabular}

\begin{tabular}{|c|c|}
\hline & $\begin{array}{l}\text { ketintang. Kemudian, } 6 \text { Orang } \\
\text { lainnya terbagi dan terkadang } \\
\text { rolling antar dua mall, yakni } \\
\text { Tunjungan Plaza dan Royal } \\
\text { Plaza) }\end{array}$ \\
\hline Pekerjaan & $\begin{array}{l}\text { Informan } 1: \text { Marketing, } \\
\text { mengantar vaksin meningitis dan } \\
\text { berbagai } \\
\text { administrasi lainnya. } \\
\text { Informan } 2 \text { : Marketing, digital } \\
\text { and design marketing, } \\
\text { pembuatan id card, dan label } \\
\text { bagasi jamaah. } \\
\text { Informan } 3: \text { Marketing, } \\
\text { mengurus berbagai persuratan, } \\
\text { dan berbagai persyaratan } \\
\text { administrasi lainnya } \\
\text { Informan } 4 \text { Marketing, } \\
\text { mengantar pembuatan paspor, } \\
\text { dan berbagai persyaratan } \\
\text { administrasi lainnya. }\end{array}$ \\
\hline $\begin{array}{l}\text { Sistem dan } \\
\text { Pola Kerja }\end{array}$ & $\begin{array}{l}\text { Karyawan bekerja Secara Tim } \\
\text { dan terbagi menjadi dua, yakni } \\
\text { tim madinah ( } 3 \text { orang) dan tim } \\
\text { makkah ( } 3 \text { orang) untuk yang di } \\
\text { mall. Tunjungan Plaza } \\
\text { dikoordinasi oleh tim madinah, } \\
\text { sedangkan Royal Plaza } \\
\text { dikoordinasi oleh tim makkah. }\end{array}$ \\
\hline \multicolumn{2}{|c|}{ Setelah Pandemi Covid-19 } \\
\hline $\begin{array}{l}\text { Jumlah } \\
\text { Karyawan }\end{array}$ & $\begin{array}{l}11 \text { ( } 2 \text { Karyawan Cuti sampai } \\
\text { pada perbaruan ketentuan yang } \\
\text { ditetapkan oleh perusahaan atau } \\
\text { sampai kondisi pulih) }\end{array}$ \\
\hline Pekerjaan & $\begin{array}{l}\text { Berdasarkan data pekerjaan yang } \\
\text { telah dipaparkan selama sebelum } \\
\text { pandemi di atas, karyawan } \\
\text { memiliki beberapa perubahan } \\
\text { dalam melaksanakan } \\
\text { pekerjaannya. Hal ini berkaitan } \\
\text { dengan adanya spesialisasi } \\
\text { pekerjaan dan peran ganda, } \\
\text { karena pekerjaan yang }\end{array}$ \\
\hline
\end{tabular}

${ }^{48}$ Hasil Observasi selama melakukan Kegiatan PPL pada tanggal 15 September-15 November 2021 


\begin{tabular}{|c|c|}
\hline & $\begin{array}{l}\text { dikerjakan ini tidak biasa } \\
\text { dilakukan pada saat sebelum } \\
\text { pandemi. Kemudian, karyawan } \\
\text { yang meng-handle pekerjaan } \\
\text { tersebut juga sedang cuti. } \\
\text { Informan } 1 \text { : Marketing, input } \\
\text { pipeline, menata buku induk, dan } \\
\text { masih mengurus beberapa } \\
\text { persyaratan administrasi seperti } \\
\text { pembuatan rekom untuk imigrasi } \\
\text { dan kemenag. } \\
\text { Informan } 2 \text { : Marketing, input } \\
\text { pipeline, digital and design } \\
\text { marketing, perlengkapan, dan } \\
\text { pembukuan operasional } \\
\text { perusahaan. } \\
\text { Informan } 3 \text { : Marketing, input } \\
\text { pipeline, mengurus berbagai } \\
\text { persuratan, dan berbagai } \\
\text { persyaratan administrasi lainnya. } \\
\text { Informan } 4: \text { Marketing, input } \\
\text { pipeline, menginput data paspor } \\
\text { (pengecekan expired paspor dan } \\
\text { vaksin meningitis), dan masih } \\
\text { mengurus beberapa persyaratan } \\
\text { administrasi seperti pembuatan } \\
\text { rekom untuk imigrasi dan } \\
\text { kemenag. }\end{array}$ \\
\hline $\begin{array}{l}\text { Sistem dan } \\
\text { Pola Kerja }\end{array}$ & $\begin{array}{l}\text { Karyawan melakukan pekerjaan } \\
\text { secara individual (tidak lagi } \\
\text { dibagi tim) dan menggunakan } \\
\text { sistem rolling (berlaku di mall } \\
\text { dan kantor) serta shift (berlaku di } \\
\text { mall) dalam bekerja. Hal tersebut } \\
\text { dikarenakan kapastitas karyawan } \\
\text { yang harus dibatasi selama } \\
\text { pandemi covid-19. Apabila di } \\
\text { kantor, maka tidak ada sistem } \\
\text { shift, karena jam kerja hari Senin } \\
\text { sampai Jumat pukul } 09.00-16.00 \\
\text { WIB dan Sabtu pada pukul } \\
\text { 09.00-14.00. Sedangkan, jika di }\end{array}$ \\
\hline
\end{tabular}

${ }^{49}$ T. Hani Handoko, Manajemen Edisi Kedua (Yogyakarta: BPFE-Yogyakarta, 2011), hlm. 200

${ }^{50}$ Andriani Nugraha dan Sylvia Diana Purba,

"Tuntutan Pekerjaan dan Stres Kerja Sebagai Variabel Penentu Turnover Intention", Jurnal

\begin{tabular}{|l|l|}
\hline & $\begin{array}{l}\text { mall, maka karyawan bekerja } \\
\text { dengan sistem shift, yakni shift } \\
\text { pertama pada pukul 10.00-17.00 } \\
\text { WIB dan shift kedua pada pukul } \\
15.00-22.00 \text { WIB. }\end{array}$ \\
\hline
\end{tabular}

1. Faktor Penyebab Stres Kerja

Karyawan Mina Wisata Islami Tour and Travel Haji Umrah mengalami kesulitan yang disebabkan oleh beberapa kondisi. Kondisi tersebut dapat memicu stres kerja dan disebut sebagai stresors oleh Handoko. ${ }^{49}$ Adapun stresors tersebut sesuai dengan yang disebutkan Handoko, yakni :

\section{Tuntutan kerja}

Tuntutan kerja meliputi suatu fokus yang berkenaan dengan pekerjaan, yakni beban kerja, cara kerja, situasi serta kondisi yang dirasakan oleh karyawan ketika bekerja. ${ }^{50}$ Berdasarkan penelitian, karyawan Mina Wisata Islami Tour and Travel Haji Umrah Surabaya memaparkan, bahwa tuntutan kerja yang di alami masih sama seperti sebelum pandemi. Tuntutan tersebut berasal dari target untuk mendapatkan jamaah pada setiap bulannya. Akan tetapi, tuntutan ini dirasa lebih berat, karena tantangannya adalah karyawan harus mendapatkan jamaah dalam kondisi pandemi yang masih berlangsung sampai saat ini. Selain itu, apabila karyawan tidak bisa mendapatkan jamaah untuk ditargetkan closing, maka ia merasa tidak nyaman dan tidak ada kontribusi dalam bekerja.

2. Peranan Ganda

Memegang peranan ganda dalam perusahaan membutuhkan usaha yang maksimal, agar dapat meminimalisir atau mencegah timbulnya konflik dalam bekerja. $^{51}$ Berdasarkan penelitian,

Manajemen dan Pemasaran Jasa (V01. 10, No. 1, Maret 2017), hlm. 51

${ }^{51}$ Arie Gunawan HZ, dkk., "Pengaruh Konflik Peran Ganda Terhadap Stres Kerja Pada Karyawan Wanita di PT. South Suco Makassar", Indonesian 
karyawan Mina Wisata Islami Tour and Travel Haji Umrah Surabaya tetap disibukkan oleh berbagai kegiatan dalam bekerja. Sehingga, tiap karyawan masih memiliki beberapa peran yang harus dihandle selama travel beroperasi di masa pandemi. Hal tersebut juga telah disampaikan oleh informan dalam penyajian data.

Para informan menyampaikan, bahwa perusahaan tetap optimal dalam memberi pekerjaan pada karyawan. Hal tersebut dibuktikan dengan beberapa pekerjaan yang harus dikerjakan selain marketing. Tiap marketing tersebut diberikan tanggung jawab yang berbeda-beda dalam pekerjaannya. Kemudian, informan tersebut juga memaparkan, bahwa terdapat kesulitan yang pasti akan terjadi dalam pengerjaan tugas yang berbeda-beda dan membuat karyawan tidak hanya fokus pada satu hal saja. Namun, pernyataan informan lain juga memaparkan, bahwa segala hal yang dilakukan tersebut baik mengenai kelengkapan data, perlengkapan, dan persyaratan jamaah merupakan bentuk kesiapan Mina Wisata Islami Tour and Travel Haji Umrah Surabaya untuk menuju normal.

Selain itu, karyawan juga memiliki beberapa perubahan dalam melaksanakan pekerjaannya. Pekerjaan tersebut berkaitan dengan adanya spesialisasi pekerjaan, karena pekerjaan yang dilakukan ini tidak biasa dilakukan pada saat sebelum pandemi. Kemudian, karyawan yang meng-handle pekerjaan tersebut juga sedang cuti.

\section{Tuntutan Waktu}

Tuntutan waktu kerja secara tidak langsung akan menambah beban kerja. Dalam hal tersebut, karyawan dituntut untuk mengerjakan suatu tugas yang

Journal of Business and Management (Vol. 3 , No. 1, Desember 2020), hlm. 140

52 Abdul Jalil, "Pengaruh Beban Kerja, Stres Kerja dan Lingkungan Kerja Terhadap Kinerja Guru Madrasah Aliyah Negeri 2 Kota Palu”, Jurnal Ilmu diberikan dalam waktu yang telah ditentukan. ${ }^{52}$

Berdasarkan penelitian, para informan memaparkan, bahwa terdapat satu tugas yang harus dikumpulkan oleh tiap marketing dalam tempo waktu satu minggu sekali. Kemudian, pengerjaannya juga diharuskan satu hari sekali. Tugas tersebut disebut dengan pipeline. Pipeline merupakan suatu tugas dalam bentuk tabel dengan berbagai kolom yang berisi datadata jamaah.

Data-data tersebut meliputi nama jamaah, paket umrah yang diingingkan, tanggal estimasi keberangkatan, tanggal follow up, estimasi closing, dan keterangan lainnya. Kemudian, pipeline tersebut dibuat dengan tujuan untuk melihat progress dari masing-masing marketing pada jamaah.

Karyawan Mina Wisata Islami juga menyampaikan beberapa kendala dalam pengerjaannnya, sehingga hal tersebut juga akan menghambat dan memicu adanya kesalahan dalam pengumpulan pipeline. Kendala tersebut juga bisa berasal dari marketing sendiri maupun customer (jamaah). Kendala dari marketing sendiri timbul karena dalam pengisian data tersebut pasti akan ada perubahan baik adanya penambahan atau pada pengeditan status jamaah pada travel, sehingga ia enggan untuk melanjutkan pengisian pipeline dan sebagainya.

Sedangkan, kendala dari jamaah berupa respon yang seadanya bahkan sampai tidak memberi respon ketika marketing mem-follow up, memberi info, maupun update info. Maka dari itu, dari adanya berbagai kendala tersebut, para informan menyampaikan, bahwa adanya tuntutan waktu tersebut membuat karyawan merasakan adanya suatu beban tersendiri dalam pengumpulan pipeline.

Perbankan dan Keuangan Islam (Vol.1, No. 2, Tahun 2019), hlm. 118 
4. Feedback yang dirasa kurang ketika melaksanakan pekerjaan

Dalam hal ini, feedback yang dimaksud adalah umpan balik antar karyawan dengan pelanggan sebagai bentuk komunikasi yang harus diterima dalam bekerja. ${ }^{53}$

Berdasarkan penelitian, tiap karyawan Mina Wisata Islami pasti mengalami feedback yang sama ketika menjalankan suatu kewajibannya sebagai marketing ketika berkomunikasi dengan customer (jamaah). Para informan juga menyampaikan, bahwa ia sebagai marketing telah melakukan pekerjaan dengan sebaik-baiknya. Hal tersebut juga dibuktikan dengan caranya yang selalu memberikan pelayanan yang baik serta selalu follow up dan update informasi pada jamaah yang berkunjung ke office, stand maupun booth Mina Wisata Islami Tour and Travel Surabaya.

Apabila marketing telah memberikan komunikasi namun tidak ada feedback yang diberikan, maka hal tersebut menunjukkan, bahwa tidak ada ketertarikan dan respect dari jamaah tersebut. Maka dari itu, feedback atau hasil umpan balik yang didapat akan menjadi titik berat bagi seorang marketing ketika berkomunikasi dengan jamaah. Jika feedback yang didapat tersebut tidak menyenangkan atau tidak dapat memberikan timbal balik yang sesuai, maka hasilnya tidak akan efektif. Sedangkan, jika dilihat dari sisi marketing, maka dalam hal ini hasil akhirnya harus ada unsur deal atau kesepakatan antara kedua belah pihak.

5. Kondisi lingkungan kerja yang tidak dapat diperkirakan

\footnotetext{
${ }^{53}$ Moh Oktaviannur, "Budaya Organisasi, Fleksibilitas Kerja, dan Feedback Terhadap Prestasi Kerja Transportasi GOJEK di Palembang", Jurnal Sains Sosio Humaniora (Vol. 4, No. 2, Desember 2020), hlm. 369-370

${ }^{54}$ Faris Lazwar Irkhami, "Faktor yang Berhubungan dengan Stres Kerja Pada Penyelam di PT. X", The Indonesian Journal of
}

Hal ini akan mendorong timbulnya ketidaknyamanan dalam bekerja. ${ }^{54}$ Berdasarkan penelitian, Karyawan Mina Wisata Islami juga mengalami perubahan pada kondisi dan lingkungan kerja. Hal tersebut disebabkan oleh pandemi yang sedang berlangsung sampai saat ini. Oleh karena itu, tiap karyawan yang bekerja di masa pandemi masih dalam proses adaptasi. Selain itu, dalam proses tersebut ditemukan ketidaknyamanan yang dapat memicu stres kerja. Ketidaknyamanan tersebut berasal dari perubahan pola dan ritme kerja.

Pada awalnya, jam kerja dibuat 8 jam per hari dengan kapasitas 2-3 orang per office. Sedangkan, saat ini karyawan hanya bekerja selama 7 jam dan hanya diisi 1-2 orang saja per office, sehingga pola kerja dirubah dengan sistem rolling atau shift. Maka dari itu, penugasan yang diberikan pada karyawan menjadi lebih detail dan karyawan juga merasa jenuh pada hal tersebut, karena tidak ada partner kerja yang dapat mengerjakan suatu pekerjaan bersama-sama seperti sebelum pandemi.

6. Wewenang yang tidak tercukupi untuk melaksanakan tanggung jawab

Seorang karyawan hanya memiliki kekuasaan dan hak untuk memberikan informasi, data, dan saran-saran yang sesuai dengan prosedur perusahaan. Hal tersebut dilakukan, agar masing-masing karyawan dapat bekerja efektif dalam mencapai tujuan perusahaan. ${ }^{55}$

Karyawan Mina Wisata Islami menyadari kewenangannya saat bekerja adalah memasarkan produk, menyampaikan informasi, dan menjaga hubungan yang baik dengan calon jamaah,

Occupational Safety and Health (Vol. 4, No. 1, Jan-Jun 2015), hlm. 54-63

${ }^{55}$ Raja Saul Marto Hendry, "Pengaruh Kepemimpinan, Wewenang Jabatan, dan Iklim Organisasi Terhadap Kinerja Karyawan Pada Dinas PUPR Kabupaten Labuhanbatu Utara”, Jurnal Informatika : Fakultas Sains dan Teknologi Universitas Labuhanbatu (Vol. 5, No.2, Mei 2017), hlm. 54 
jamaah, maupun alumni. Akan tetapi, terdapat persoalan yang mengakibatkan karyawan merasa dalam hal ini, ia tidak memiliki kewenangan dalam melaksanakan tanggung jawabnya sebagai marketing dan tidak bisa menilai karena ada banyak faktor yang menyebabkan hal tersebut dapat terjadi.

Berdasarkan data yang dipaparkan oleh karyawan Mina Wisata Islami Tour and Travel, menyatakan bahwa dalam pembelian, setiap keputusan yang diambil oleh jamaah bukan merupakan kewenangannya. Sedangkan, sistem marketing bisa dikatakan baik apabila ia berkontribusi dalam penjualan dan berusaha untuk mencapai target perusahaan.

Dalam hal ini, customer juga memiliki banyak faktor yang perlu dipertimbangkan dalam membeli suatu produk. Begitupun juga dengan keinginannya untuk merefund suatu pembelian. Sehingga, marketing tidak bisa berbuat banyak atas hal tersebut.

2. Upaya dan Hambatan dalam Penangggulangan Stres Kerja di Masa Pandemi Covid-19 pada Karyawan Mina Wisata Islami Tour and Travel Haji Umrah

a. Upaya Karyawan

Karyawan Mina Wisata Islami memiliki upaya sendiri dalam mengatasi permasalahan stres dalam bekerja. Berdasarkan upaya karyawan untuk mengatasi stres kerja di masa pandemi, peneliti dapat menganalisa, bahwa hal ini hanya sejalan dengan ketiga dari keempat teori yang dikemukakan oleh Mangkunegara yang dikutip oleh Shandy dan Neni. Teori tersebut menjelaskan bahwa stres kerja dapat ditanggulangi melalui empat metode. ${ }^{56}$

\footnotetext{
${ }^{56}$ Shandy E. Santayana dan Neni Triastuti,

"Analisis Stres Kerja Pada Karyawan PT.

Perkebunan Nusantara IV Kebun Bah Jambi",

Jurnal Bisnis Administrasi (Vol. 2, No. 2, 2013), hlm. 50
}

Pertama, melalui metode dukungan sosial yang ditunjukkan oleh pemberian motivasi secara individu maupun tim dan saling membantu antar sesama karyawan dalam bekerja. Kedua, melalui metode penenangan diri yang ditunjukkan oleh karyawan Mina Wisata Islami yang selalu berfikir positif serta dapat menerima segala tuntutan dan memahami bahwa tuntutan yang ada dalam kondisi seperti ini merupakan ujian yang harus dihadapi baik untuk karyawan maupun perusahaan.

Ketiga, melalui metode biofeedback. Metode ini tidak dilakukan oleh karyawan Mina Wisata Islami Surabaya, karena stes kerja yang dialami tidak sampai mengarah pada hal-hal yang negatif. Selain itu, karyawan Mina Wisata islami juga selalu memfokuskan diri pada hal yang positif, sehingga stres kerja tersebut dapat dikelola dan dapat memicu untuk menghasilkan kinerja yang positif. Keempat, melalui metode evaluasi diri sebelum, selama, dan sesudah melakukan pekerjaan.

Hal tersebut juga ditunjukkan oleh sikap tiap karyawan Mina Wisata Islami ketika melakukan penilaian kinerja baik sebelum, selama, dan sesudah melakukan pekerjaan tersebut. Karyawan Mina Wisata Islami selalu memikirkan yang terbaik untuk mencapai hasil yang optimal sebelum melakukan pekerjaan. Kemudian, ia selalu berusaha secara maksimal untuk dapat menyelaraskan antara kinerja, tugas, dan waktu yang diberikan selama melakukan pekerjaan tersebut. Selain itu, ia juga selalu berdiskusi mengenai hasil pekerjaan tersebut serta meminta saran dan solusi baik kepada sesama karyawan maupun pimpinan setelah melakukan pekerjaan. $^{57}$

\section{b. Upaya Perusahaan}

\footnotetext{
${ }^{57}$ Hasil Observasi selama melakukan Kegiatan PPL pada tanggal 15 September-15 November 2021
} 
Peran perusahaan juga sangat penting dalam mengatasi tiap permasalahan yang dapat memicu stres kerja pada karyawan Mina Wisata Islami Tour and Travel Haji Umrah. Perusahaan telah melakukan banyak upaya, yakni pemberian motivasi, reward, dan berbagai bentuk hal yang dapat dikatakan sebagai upaya perusahaan dalam menanggulangi stres kerja.

Dalam hal ini, peneliti dapat menganalisa, bahwa hal ini sejalan dengan keempat teori yang dikemukakan oleh Mangkunegara yang dikutip oleh Shandy dan Neni. Teori tersebut menjelaskan bahwa stres kerja dapat ditanggulangi melalui empat metode. ${ }^{58}$

Pertama, melalui metode dukungan sosial yang ditunjukkan oleh pemberian tambahan insentif sebagai motivasi dan reward kepada masing-masing karyawan yang dapat mencapai target perusahaan. Selain itu, pipeline juga dapat dikatakan sebagai upaya perusahaan dalam menanggulangi stres kerja yang dialami karyawan, karena melalui pengisian pipeline, karyawan dapat melihat peluang jamaah yang akan didapatkan dan datanya dapat tersusun dengan baik. Pipeline juga membantu karyawan untuk lebih mengenal tiap-tiap jamaah yang dihandle. Kedua, melalui metode penenangan diri yang ditunjukkan oleh sikap pimpinan yang selalu membawa dan menyampaikan halhal positif pada seluruh karyawan didalam ruang lingkup pekerjaan.

Ketiga, melalui metode biofeedback yang didukung oleh adannya sistem perusahaan yang memiliki seorang ustadz, sehingga dapat memberikan motivasi secara spiritual dengan memberi tausiyah yang diadakan sekali setiap minggu. Dengan begitu, stres kerja dapat dikelola dan direda dengan baik. Hal tersebut juga

\footnotetext{
${ }^{58}$ Shandy E. Santayana dan Neni Triastuti,

"Analisis Stres Kerja Pada Karyawan PT.

Perkebunan Nusantara IV Kebun Bah Jambi”, Jurnal Bisnis Administrasi (Vol. 2, No. 2, 2013), hlm. 50
}

menjadi penguat yang penting secara batiniah untuk kondisi psikologis masingmasing karyawan.

Keempat, melalui metode evaluasi. Hal tersebut dapat dilihat dari kegiatan rutinitas perusahaan dalam melihat progress tiap karyawan Mina Wisata Islami, yakni dengan memberikan evaluasi pada pengumpulan dan pembahasan pipeline di hari Senin. ${ }^{59}$ Selain itu, hal tersebut juga sebagai cara untuk mencari solusi bersama, agar tiap karyawan tidak merasakan masalah dan menanggung beban secara individual.

c. Hambatan Karyawan maupun Perusahaan dalam Upaya Penanggulangan Stres Kerja

Siagian mengkategorikan sikap manusia menjadi dua kelompok dalam mengendalikan hidupnya. Pertama, seseorang yang bersikap optimis dan percaya, bahwa takdir ditentukan oleh diri sendiri. Kedua, seseorang yang beranggapan bahwa ia hanya sebagai pemeran dalam hidupnya dan pihak lain yang dapat mengatur peran yang akan dijalankan. ${ }^{60}$

Berdasarkan penelitian, peneliti dapat menganalisa bahwa Mina Wisata Islami Tour and Travel Surabaya termasuk dalam kelompok pertama, yakni bersikap optimis dan percaya, bahwa takdir ditentukan oleh diri sendiri. Hal tersebut dikarenakan prinsip dan tujuan Mina Wisata Islami yang tetap dipegang sampai saat ini. Pemimpin tetap memiliki prinsip bahwa perusahaan yang dijalani ini harus tetap beroperasi dan harus dengan bidang yang sama, yakni wisata religi Haji dan Umrah.

Dalam mengatasi segala permasalahan dan tuntutan kerja selama pandemi, peneliti dapat menganalisa, bahwa terdapat beberapa hal yang dapat memicu dan mengarah pada suatu permasalahan,

\footnotetext{
${ }^{59}$ Hasil Observasi selama melakukan Kegiatan PPL pada tanggal 15 September-15 November 2021

${ }^{60}$ Sondang P Siagian, Teori Pengembangan Organisasi, (Jakarta: Bumi Aksara, 2000), hlm. 147-148
} 
bahkan bisa dikatakan sebagai hambatan dalam penanggulangan stres kerja di masa pandemi. Permasalahan tersebut sejalan dengan teori yang dipaparkan oleh Lathifah Hanum, dkk.

Apabila seorang karyawan hanya meyakini dan menggunakan teknik emotion focused coping dan religious focused coping dalam menanggulangi stres, maka ia tidak akan bisa memecahkan masalah dengan baik dan cepat, sehingga permasalahan tersebut akan mudah terulang kembali di masa yang akan datang. ${ }^{61}$ Kemudian, teori tersebut didukung oleh pernyataan informan yang memaparkan, bahwa ia selalu berfikir positif dalam mendapatkan jamaah, meskipun ia mengetahui hal ini akan susah dilakukan pada kondisi yang serba tidak pasti seperti sekarang ini.

Dalam memperoleh hasil, ia hanya percaya akan rezeki dan menyerahkan semuanya pada yang maha kuasa. Maka dari itu, peneliti menganalisa, bahwa jika karyawan cukup bergantung pada hal tersebut, maka ia tidak akan bisa mendapatkan hasil yang maksimal dan cenderung pasrah dengan hasil yang telah didapat.

Selain itu, peneliti menemukan hal lain yang dapat menghambat upaya penanggulangan stres kerja di masa pandemi pada karyawan Mina Wisata Tour and Travel Haji Umrah Surabaya, yakni :

1. Ketidakefektifan Kerja, Ketidakefisienan Waktu, dan Ketidakjelasan Informasi

Dalam hal ini, adapun stressor terjadi pada karyawan Mina Wisata Islami yang disebabkan oleh keterkaitan antara tuntutan waktu serta peranan ganda ketika bekerja. Pada upayanya, peneliti menemukan adanya suatu persoalan yang dialami oleh karyawan Mina Wisata Islami.

\footnotetext{
${ }^{61}$ Lathifah Hanum, dkk, "Penerapan Manajemen
} Stres Berkelompok dalam Menurunkan Stres pada
Karyawan Mina Wisata Islami Tour and Travel Surabaya menjelaskan, bahwa peran ganda dan tuntutan waktu dapat diupayakan dengan memilah serta memprioritaskan tugas berdasarkan waktu atau jadwalnya. Akan tetapi, tak dapat dipungkiri, bahwa akan selalu ada tugas yang mendadak dan harus diselesaikan pada saat itu juga. Sehingga, karyawan diharuskan untuk segera mengerjakannya dan meninggalkan pekerjaan lain.

Hal tersebut tentunya akan menghambat pekerjaan lainnya, sehingga terjadi penundaan dan pengesampingan tugas dalam pengerjaannya. Kemudian, ia juga memaparkan bahwa semua tugas tersebut pasti akan selesai. Karyawan juga merasa, bahwa ia efektif dalam bekerja, karena ia mampu mengerjakan hingga tuntas. Walaupun, ia menyadari, bahwa pekerjaan yang telah diberikan sebelumnya kemungkinan juga pasti akan membutuhkan waktu lebih dari yang telah ditentukan oleh perusahaan.

Peneliti menganalisa, bahwa hal tersebut tidak bisa dikatakan cukup efektif, karena pengerjaannya yang cukup membutuhkan waktu lebih lama dari yang ditentukan dan pengumpulannya yang tidak tepat pada waktunya, meskipun ia telah selesai melaksanakan tugasnya. Jika suatu hal yang dikerjakan tersebut berkenaan dengan manajemen operasioal perusahaan, maka hal tersebut tentu akan menghambat segala aktivitas atau kegiatan yang harusnya dilakukan dalam dekat waktu. Selain itu, dalam menjaga komunikasi dan keinginan untuk mendapat feedback yang setimpal, ketidakjelasan informasi juga akan menghambat segala upaya yang telah direncanakan dan strategi yang akan dibuat perusahaan. Hal tersebut dikarenakan informasi sangat berguna dalam melaksanakan sekaligus melancarkan kegiatan pemasaran terutama

Lanjut Usia Berpenyakit Kronis", Jurnal Psikologi (Vol. 43, No. 1, 2016), hlm. 48 
mengenai ibadah umrah di masa pandemi covid-19.

2. Karakteristik Individu

Adanya atau timbulnya

karakteristik yang buruk pada karyawan disebabkan oleh kesulitan-kesulitan yang telah ia temukan dalam bekerja. Selain itu, karakteristik ini juga dapat timbul, karena ia menganggap dan memandang tugas tersebut sebelah mata.

Dalam hal ini, peneliti menemukan suatu hambatan dalam upaya penanggulangan stres kerja yang disebabkan oleh peranan ganda dan tunutan waktu. Hambatan tersebut berasal dari karyawan yang seringkali merasa enggan dan tidak memiliki keharusan dalam mengerjakan serta mengumpulkan tugas yang telah diberi oleh perusahaan. Hal ini dapat terjadi, karena ia juga merasa sudah cukup menjalankan, memenuhi dan melakukan tanggung jawabnya.

Berdasarkan pernyataan tersebut, peneliti dapat menganalisa, bahwa apabila karakteristik tersebut timbul dalam diri karyawan saat bekerja, maka hasil dari ia bekerja tidak akan bisa dievaluasi dan sulit bagi perusahaan dalam melihat progress yang telah dilakukan setiap minggunya. Selain itu, jika ada suatu permasalahan yang muncul di kemudian hari, maka ia tidak akan bisa menanyakan atau berbagi solusi dengan rekan kerja atau pimpinannya, karena catatan progress yang dijadikan acuan untuk melihat peluang, mencari solusi, serta pembuatan keputusan dalam mengambil strategi tersebut tidak ada.

3. Kondisi Finansial Perusahaan Peneliti juga mendapatkan informasi yang dikatakan dapat menjadi suatu strategi sekaligus hambatan perusahaan dalam beroperasi di masa pandemi.

Dalam operasionalnya, perusahaan tentu membutuhkan biaya yang tidak sedikit. Selain itu, Mina Wisata Islami juga merupakan perusahaan yang bergerak di bidang Haji dan Umrah, sedangkan ibadah ini tidak bisa berjalan di kondisi pandemi. Maka dari itu, secara otomatis perusahaan juga mendapatkan omset yang minim atau bahkan tidak ada omset.

Akan tetapi, berdasarkan hasil penelitian, perusahaan tetap memberi hak karyawan setelah bekerja, bahkan dapat memberikan insentif apabila karyawan dapat memenuhi target perusahaan. Namun, karyawan juga memaparkan, bahwa manajemen perusahaan pasti memiliki strategi tersendiri dalam mengatasi hal tersebut, yakni dengan cara mengambil tabungan atau omset perusahan selama sebelum pandemi.

Berdasarkan pernyataan tersebut, peneliti juga memahami bahwa hal tersebut dapat dikatakan sebagai strategi perusahaan. Akan tetapi, peneliti juga menganalisa, bahwa strategi ini juga merupakan sebuah hambatan bagi perusahaan ketika beroperasi, karena perusahaan telah minim bahkan tidak memiliki omset di masa pandemi. Kemudian, jika perusahaan hanya terfokus pada cara penanggulangan tersebut, maka hal ini dapat memicu timbulnya permasalahan pada finansial perusahaan di masa yang akan mendatang.

\section{Kesimpulan}

1. Faktor Penyebab Stres Kerja pada Karyawan Mina Wisata Islami Tour and Travel Haji Umrah Surabaya

Stres kerja merupakan suatu respon yang timbul terhadap siklus perubahan lingkugan dan mengarah pada hal yang spesifik sesuai dengan kondisi yang ada. Perubahan lingkungan yang dimaksud adalah masa pandemi covid19, sehingga hal ini dapat menimbulkan banyak perasaan khawatir hingga tidak nyaman yang ada dalam diri karyawan Mina Wisata Islami ketika bekerja.

Faktor penyebab stres kerja pada karyawan Mina Wisata Islami didominasi oleh perubahan kondisi dan 
ketidakjelasan informasi secara bersamaan, sehingga karyawan tidak memiliki kuasa atas hal tersebut. Adapun beberapa stressor (kondisi) lainnya yang dapat memicu timbulnya stres kerja bagi karyawan, yakni tuntutan kerja, tuntutan waktu, peranan ganda, feedback yang dirasa kurang setelah ketika melaksanakan pekerjaan, kondisi lingkungan kerja, dan wewenang yang tidak tercukupi untuk melaksanakan tanggung jawab.

2. Upaya dan Hambatan Penanggulangan Stres Kerja di Masa Pandwemi Pada Karyawan Mina Wisata Islami Tour and Travel Haji Umrah Surabaya

a. Upaya penanggulangan stres kerja di masa pandemi covid-19 dilakukan dengan cara

1) Oleh Karyawan

Dalam hal ini, adapun tiga metode dalam upaya penanggulangan stres kerja yang dilakukan oleh karyawan, yakni dukungan sosial (motivasi antar sesama karyawan), penenangan diri, dan evaluasi diri.

2) Oleh Perusahaan

Perusahaan menggunakan empat metode daalam menanggulangi stres kerja di masa pandemi covid-19 pada karyawan Mina Wisata Islami Tour and Travel Haji Umrah Surabaya. Metode tersebut diantaranya adalah melalui dukungan sosial (pemberian tambahan insentif sebagai motivasi dan reward kepada masing-masing karyawan), penenangan diri, biofeedback, dan evaluasi.

b. Hambatan dalam upaya penanggulangan stres kerja di masa pandemi covid-19

1) Bagi Karyawan

Adapun hambatan dalam upaya penanggulangan stres kerja di masa pandemi yang ada pada diri karyawan, karena suatu teknik yang diambil dalam mengatasi segala tuntutan atau permasalahan yang ada. Teknik tersebut diantaranya adalah emotion focused coping dan religious focused coping. Selain itu, terdapat beberapa hambatan lain yang dapat mengganggu proses upaya penanggulangan stres kerja, yakni ketidakefektifan kerja, ketidakefisienan waktu, ketidakjelasan informasi, dan karakteristik individu.

2) Bagi Perusahaan

Sedangkan, hambatan perusahaan dalam upaya penanggulangan stres kerja pada karyawan disebabkan oleh kondisi finansial ketika beroperasi di masa pandemi.

\section{Daftar Pustaka}

Abdullah bin Muhammad bin 'Abdurrahman bin Ishaq Alu Syaikh. Tafsir Ibnu Katsir Jilid 2. Bogor: Pustaka Imam Asy-Syafi'i. 2007.

Anoraga, Panji. 2014. Psikologi Kerja. Jakarta: Rineka Cipta.

Ardani, Juli dkk. Maret 2017. “Analisis Faktor-Faktor Penyebab Stres Kerja Pada StafRekam Medis di Rumah Sakit Umum Daerah Kota Mataram”. Jurnal Magister Manajemen Universitas Mataram. Vol. 6. No. 1

Asrun, Muhammad dan Annisaa Miranty Nurendra. 2021. "Meningkatkan Resiliensi Masyarakat yang Terkena PHK di Masa Pandemi Menurut Perspektif Psikologi Islam". Motiva: Jurnal Psikologi. Vol. 4. No. 1

Baqiyatul Auladiyah, "Islam dan Stress Kerja",

https://studiislamkomprehensif.blog spot.com/2016/02/islam-dan-stresskerja-baqiyatul.html, diakses melalui web pada tanggal 11 September 2021, pukul 11.54 WIB.

Budiyati, Gani Apriningtyas dan Eka Oktavianto. November 2020. "Stress dan Resiliensi Remaja di Masa Pandemi Covid-19". Husada Mahakam : Jurnal Kesehatan. Vol. 10. No. 2

Gaol, Lumban. 2016. "Teori Stres: Stimulus, Respons, dan Transaksional". Buletin Psikologi. Vol. 24. No. 1 
Gibson, Ivancevich, dan Donnelly. 1996. Organisasi. Jakarta: Binarupa Aksara

Handoko, T. Hani. 2011. Manajemen Edisi Kedua. Yogyakarta: BPFEYogyakarta.

Hanum, Lathifah, dkk,. 2016. "Penerapan Manajemen Stres Berkelompok dalam Menurunkan Stres pada Lanjut Usia Berpenyakit Kronis". Jurnal Psikologi. Vol. 43. No. 1

Hendry, Raja Saul Marto. 2017. "Pengaruh Kepemimpinan, Wewenang Jabatan, dan Iklim Organisasi Terhadap Kinerja Karyawan Pada Dinas PUPR Kabupaten Labuhanbatu Utara”. Jurnal Informatika : Fakultas Sains dan Teknologi Universitas Labuhanbatu. Vol. 5. No.2

HZ, Arie Gunawan, dkk. 2020. "Pengaruh Konflik Peran Ganda Terhadap Stres Kerja Pada Karyawan Wanita di PT. South Suco Makassar". Indonesian Journal of Business and Management. Vol. 3. No. 1

Indra, Syaiful dkk. 2020. "Emotion Focused Coping Dalam Mereduksi Kecemasan Pada Masa Pandemi Covid-19”. JUANG: Jurnal Wahana Konseling. Vol. 3. No. 2

Irkhami, Faris Lazwar. 2015. "Faktor yang Berhubungan dengan Stres Kerja Pada Penyelam di PT. X", The Indonesian Journal of Occupational Safety and Health. Vol. 4. No. 1

Jalaluddin As Suyuthi dan Jalaluddin Muhammad Ibnu Ahmad AlMahally, "Tafsir Jalalain", E-Book, hlm. 193.

Jalil, Abdul. 2019. "Pengaruh Beban Kerja, Stres Kerja dan Lingkungan Kerja Terhadap Kinerja Guru Madrasah Aliyah Negeri 2 Kota Palu”. Jurnal Ilmu Perbankan dan Keuangan Islam. Vol.1. No. 2

K, Zalfa. 2009. "Hubungan Antara Tingkat Religiusitas dengan Strategi Coping pada Santri Pondok Pesantren Nurul Huda Mergosono Malang. Skripsi.
Malang: Fakultas Psikologi. UIN Maulana Malik Ibrahim.

Kemkes RI Pusat Kesehatan Haji, https://puskeshaji.kemkes.go.id/be rita/2020/11/12/ber-haji-dan-berumrah-di-masa-pandemi-covid-19, diakses melalui web pada tanggal 20 Juli 2021, pukul 23.14 WIB.

Mangkunegara, A. A. Anwar Prabu. 2013. Manajemen Sumber Daya Manusia Perusahaan. Bandung: PT Remaja Rosdakarya.

Maserati, Giszka Gita dan Herison Pandapotan Purba. 2021. "Pengaruh Stres Kerja dan Coronavirus Anxiety terhadap Mental Well-Being pada Generasi Milenial". Buletin Riset Psikologi dan Kesehatan Mental (BRPKM). Vol. 1. No. 1

Munandar, Ashar Sunyoto. 2001. Psikologi Industri dan Organisasi. Jakarta: UI Press.

Nugraha, Andriani dan Sylvia Diana Purba. 2017. "Tuntutan Pekerjaan dan Stresm Kerja Sebagai Variabel Penentu Turnover Intention". Jurnal Manajemen dan Pemasaran Jasa. Vol. 10. No. 1

Oktaviannur, Moh. 2020. "Budaya Organisasi, Fleksibilitas Kerja, dan Feedback Terhadap Prestasi Kerja Transportasi GOJEK di Palembang". Jurnal Sains Sosio Humaniora. Vol. 4. No. 2

Rasdam, Rismayanti dkk,. Oktober 2018. "Analisis Pengaruh Lingkungan Kerja, Kompensasi, dan Stress Kerja Terhadap Semangat Kerja dan Dampaknya Terhadap Kinerja Karyawan". Hasanuddin Journal of Applied Business and Entrepreneurship/HJABE. Vol. 1. No. 4

Rasyid, Muhammad. Desember 2017. "Analisis Hubungan Lingkungan 